研究

\title{
超塑性窒化けい素の作製
}

\author{
西村 聡之的，三友護々1，廣津留秀樹的2 \\ 科学技術庁無機村質研究所, テ305つくば市亚木1-1.

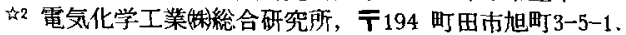

\section{Fabrication of Superplastic Silicon Nitride Ceramics}

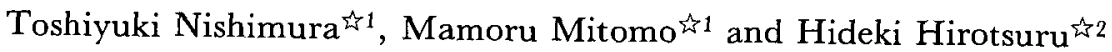 \\ it National Institute for Research in Inorganic Materials, 1-1 Namiki, Tsukuba 305. \\ ir2 Res. Cent. Denki Kagaku Kogyo K.K., 3-5-1 Asahi-machi, Machida 194.
}

Received July 20, 1995

\section{SYNOPSIS}

Effect of particle size of raw powder on the sintering and grain growth of silicon nitride ceramics was invesitigated. $\beta$-silicon nitride powder, which is stable at high temperature, was used to eliminate the effect of phase transformation. Fine powder was made from commercial submicrometer powder by removing particles of over $0.5 \mu \mathrm{m}$ in diameter using grinding and centrifugal sedimentation. The fine and submicrometer powders were sintered by hot-pressing. Fine-grained silicon nitride ceramics was fabricated from the fine powder. This fine grained ceramics deformed at a strain rate of $1.8 \times 10^{-4} / \mathrm{s}$ under $1500{ }^{\circ} \mathrm{C}$ and $40 \mathrm{MPa}$ of compressive stress, i.e. it had superplasticity. Microstructure of the fine-grained ceramics was stable on annealing at $1800{ }^{\circ} \mathrm{C}$ for th. The grain growth rate during hot-pressing and annealing of submicrometer powder was larger than that in fine powder. It was revealed that the difference in grain size is a main driving force for the grain growth. Fine and homogeneous particle size distribution of raw powder is necessary to fabricate superplastic silicon nitride ceramics.

\section{KEY WORDS}

silicon nitride, fine-grained, particle size distribution, superplasticity, microstructure

\section{1 腥言}

窒化けい素セラミックスは典型的な脆性材料であ るセラミックスの中では勒性が高く，高温での強度 も高い。その特性を生かし，ガスタービンの部材な ど高温構造材料として実用化に向けて研究が進めら れている. セラミックスの実用化を阻む一因に加工 の困難さがある．セラミックスは通常高温において も脆性なため，金属と異なり塑性加工を行うことが できない，そこで従来は複雑形状のセラミックスを 作製する場合には粉末成形体の段階で加工を行い，
焼結体作製後にさらにダイヤモンド工具などを用い て研削加工を行ってきた. そのため生産コストの上 昇は避けられなかった。

近年窒化けい素/炭化けい素 ${ }^{1)}$ ，あるいは $\alpha / \beta$ サイアロン ${ }^{2)}$ の複合系で，微細な粒子からなる窒化 けい素基材料が超塑性を持つことが報告され，塑性 加工への応用が期待されている．また著者らは粒度 の揃ったナノメータサイズの粒子からなる高温安定 な $\beta$ 型の空化けい素粉末を短時間に䇠成して微細な 粒子からなる単相の窒化けい素セラミックスを作製 
し，このセラミックスが超塑性を示すことを報告し $た^{3)}$. これらの超塑性窒化けい素系セラミックスは いずれも微細な粒子から成り, これが超塑性セラミ ックスの特徵である. 複合系の窒化けい素セラミッ クスでは超塑性変形中に粒成長が起こり（動的粒成 長）, 変形能が低下すること（加工硬化現象）が報 告されている ${ }^{122)}$. したがって速いひずみ速度で大 きなひずみを得るためには, 超塑性変形中に動的粒 成長が起こらない, 安定な微構造であることが望ま しい.

これまでの報告では高温安定な $\beta$ 型窒化けい素で 粒度の揃ったナノメータサイズの粒子を出発原料と した場合には超塑性を示すナノセラミックスが得ら れた.これは超塑性変形中に粒成長を起こさず加工 硬化は起こらないことがわかっている ${ }^{3)}$. しかし低 温安定な $\alpha$ 型の微細で粒度の揃った粉末を出発原料 とした場合には，低温で短時間にホットプレス焼結 を行うと微細で均一な組織からなる焼結体が得られ るが, その後熱処理を行うと異常粒成長が起こるこ とが報告されている ${ }^{4)}$.この結果から $\alpha$ 型の粉末は 微構造の安定性の点から超塑性セラミックスの作製 にはふさわしくないことがわかる.

そこで本研究では高温安定な $\beta$ 型の窒化けい素で 粒度の異なる 2 種類の粉体を原料として, 原料粉体 の粒度の相连に焦点を絞り, 窒化けい素の焼結と粒 成長に及ぼす影響について検討する.

\section{2 実験方法}

市販の $\beta$ 型のサブミクロンの窒化けい素（電気化 学工業製, P21FC, 以下サブミクロン粉と呼ぶ）を湿 式法により粉砕し, 遠心分級により $0.5 \mu \mathrm{m}$ 以下の粒 子のみを分取した（以下微粉と呼ぶ）. 光透過法を用 い粒度分布を測定した. 微粉およびサブミクロン粉 に焼結助剂として $\mathrm{Y}_{2} \mathrm{O}_{3}$ (純度 $99.9 \%$, 信越化学製) を $5 \mathrm{wt} \%, \mathrm{Mg} 0$ (試楽特級, 和光純薬製) を $2 \mathrm{wt} \%$ 添加 し, これらを窒化けい素製のボールとポットを用い, 遊星ミルで混合した. 焼結はホットプレス法を用い た. 窒素気流中, 20MPaで加圧しながら, $30^{\circ} \mathrm{C} / \mathrm{min}$ の 一定昇温速度で加熱し, 密度が90\%を越えた時点で直 ちに電源を断って冷却した.これは高密度化を達成 し, かつ粒成長を最小限に押さえるためである. そ の結果, 焼結温度は微粉の場合は $1700^{\circ} \mathrm{C}$, サブミク ロン粉の場合は $1800^{\circ} \mathrm{C}$ となった. 焼結体は円柱状で あり, 直径, 厚さ, 質量からかさ密度を算出した.
ホットプレス焼結体の粒成長挙動を検討するため, $1 \mathrm{MPa}$ 窒素中, $1800^{\circ} \mathrm{C}$ て 1 時間熱処理を行った. 焼結 体の研磨面を $0_{2}$ を $7.8 \%$ を含んだCF 4 中でプラズマエ ッチングし, 走査型電子顕微鏡により微構造を観察 した. 画像解析により見かけの平均円相当径を算出 した. 見かけの平均円相当径は, 各粒子の面積を小 さいものから積算し, 全粒子面積の $50 \%$ たったと きの粒子の面積と等しい円の直径として求めた. 各 試料とも1000個以上の粒子について計算した.

\section{3 結果と考察}

\section{1 粉体特性}

図1に実験に供した粉体の走査型電子顕微鏡写真を 示す. 微粉は $0.3 \mu \mathrm{m}$ 程度の粒子のみからなる粒度の

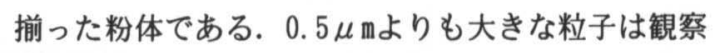
されない. サブミクロン粉は $1 \mu \mathrm{m}$ 程度の比較的大き な粒子の他に $0.5 \mu \mathrm{m}$ 以下の微細な粒子が観察され, 粒度分布の広い粉体であることがわかる. 図2に光透 過法により測定した粒度分布を示す. 微粉の50\%径

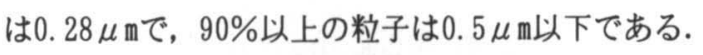
$0.5 \mu \mathrm{m}$ り もきな粒子が検出されているが, 図1で このような大きさの粒子は観察されていないことを

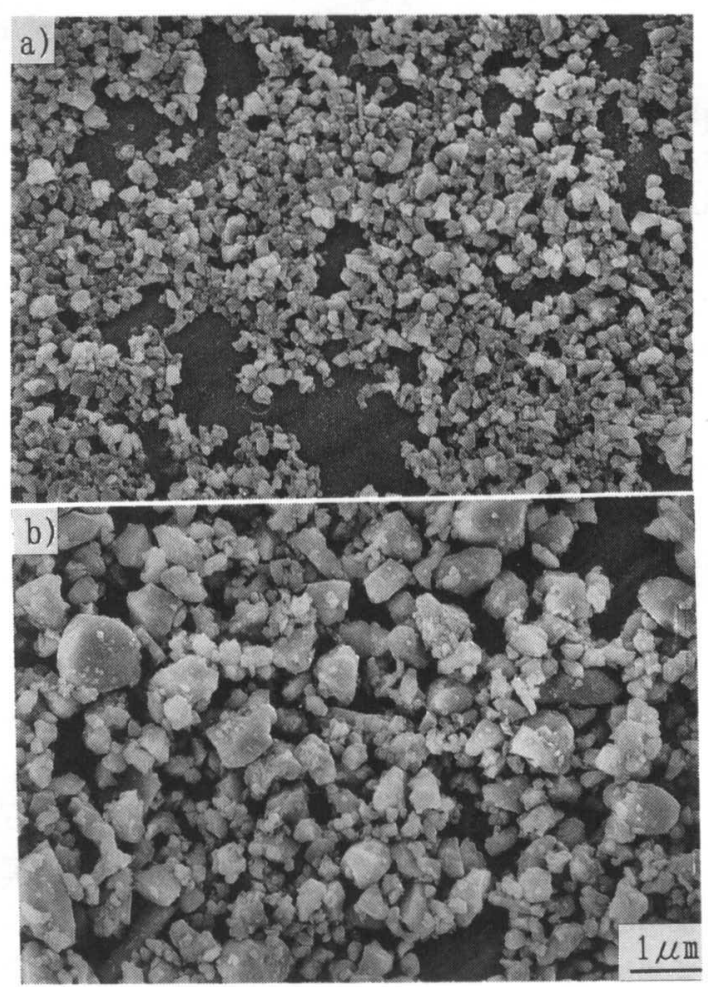

Fig.1 SEM micrograph of (a)fine and (b)submicrometer powders. 
考慮すると，実際には微粉が結合した2次粒子による と考えられる. サブミクロン粉の $50 \%$ 径は $0.51 \mu \mathrm{m}$, $90 \%$ 径は約 $1 \mu \mathrm{m}$ である. これらの結果より, 微粉で は分級により， $0.5 \mu \mathrm{m}$ よも大きな粒子は取り除か れていることが確認された.この大きな粒子の有無 が微粉とサブミクロン粉の粒度の主な相違である.

\section{2 高密度化と粒成長}

図3にホットプレス中の䌡密化曲線を示す. 微粉は $1700^{\circ} \mathrm{C}$ ま゙の加熱でほぼ相対密度 $100 \%$ に達している

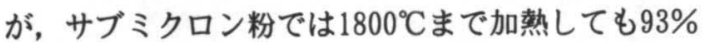
にとどまっている. 微粉はサブミクロン粉に比較し て低温で焼結が進行することがわかる.

図4にホットプレス焼結体の組織を示す. 微粉を焼 結した場合(a)には, 組織は細かく均一な粒子から構 成されている，画像解析により求めた見かけの平均

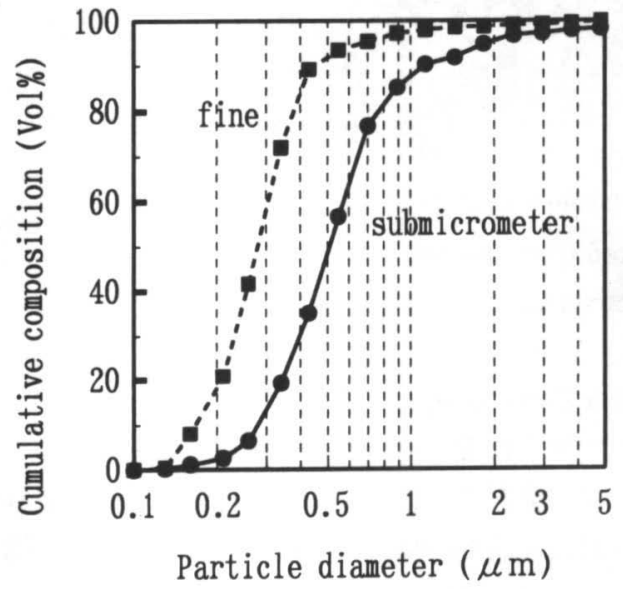

Fig.2 Particle size distribution of powders.

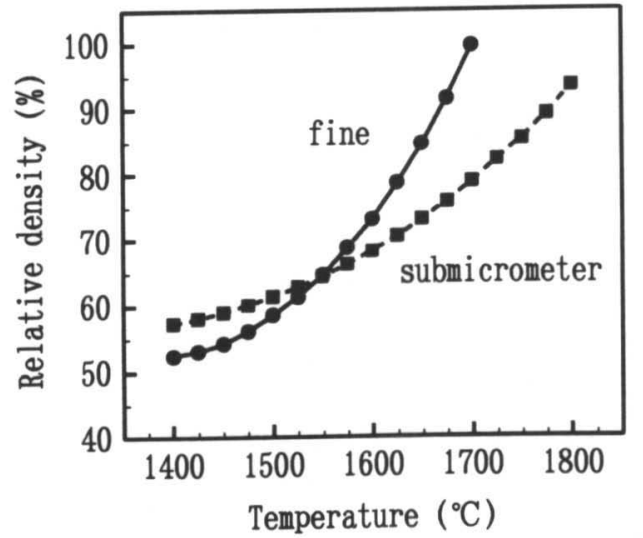

Fig.3 Densification behavior of powders during hotpressing.
円相当径は0. $21 \mu \mathrm{m}$ である. 低温で焼結を行ったため, 原料の微粉（図1(a)）と比較しても粒成長はほとん ど起こっていない. 他方サブミクロン粉の場合 (b)は, 組織は比較的均一であるがほとんどの粒子は $0.5 \mu \mathrm{m}$ 以上の粒子径をもつ. 見かけの平均円相当径は 0.68 $\mu \mathrm{m}$ であ. 原料粉中に含まれていた $0.5 \mu \mathrm{m}$ 以下の粒 子はほとんど大きな粒子に吸収され, 粒成長が起こ っている.

微粉をホットプレスして得られた焼結体を $1500^{\circ} \mathrm{C}$, 40MPaの圧縮応力下で変形させたところ，ひずみ速度 $1.8 \times 10^{-4} / \mathrm{s}$ で超塑性変形した. 図5に超塑性加工の 例を示す.これらはすべて円柱状の試料から得られ たものである. 複雑形状にも加工可能である ${ }^{5)}$.

$\beta$ 型の粉体を出発原料とした場合の焼結と粒成長 については既に報告がある ${ }^{6)}$. 市販の $\alpha$ 型の窒化け い素粉末を熱処理し $\beta$ 型に転移させた粉末を焼結温 度1850〜2000 Cでガス圧焼結した場合には, 焼結温 度の上昇に従い粒成長するものの, 粒径分布の形は 不変であり, 平均粒径で規格化すると粒径分布曲線 は重なる.このことから焼結体の微構造は原料粉体 の粒度により決定されることが示唆されている ${ }^{6)}$.
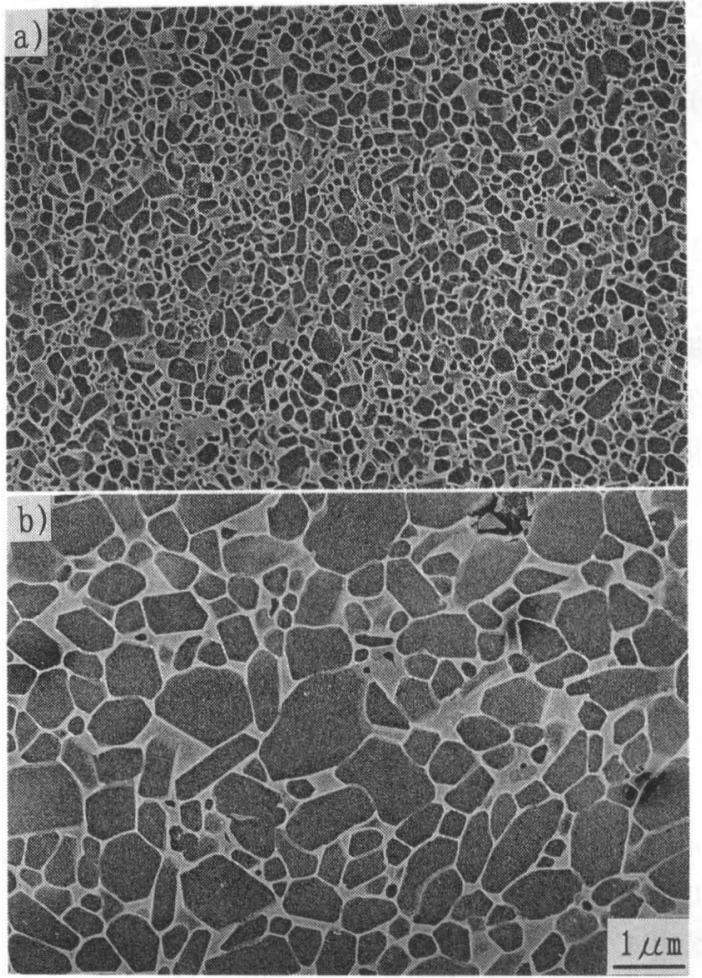

Fig.4 SEM micrographs of hot-pressed silicon nitride ceramics prepared from (a)fine and (b)submicrometer powders. 


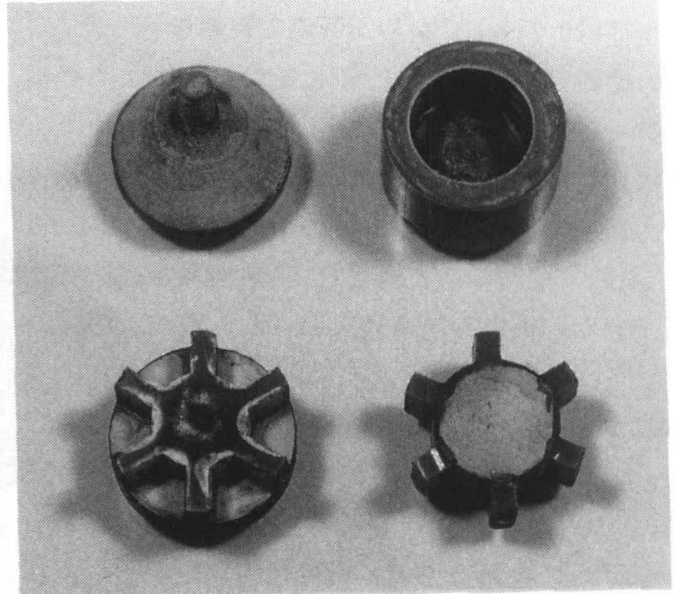

Fig.5 Examples of complexly shaped materials prepared by superplastic deformation of cylindrical disks $^{5 \text { ) }}$.

本実験の結果でもホットプレス中の高密度化, 粒成 長は0. $5 \mu \mathrm{m}$ より大きな粒子の有無により大きな差

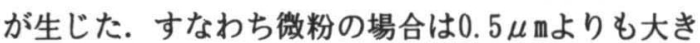
な粒子が存在しないため低い焼結温度で高密度化を 達成し，粒成長を抑えることができ，均一で微細な 組織となり，超塑性を示した．サブミクロン粉の場

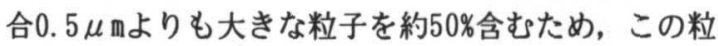
子が核となり粒成長が起こり，均一ではあるが粗大 な組織となった。

\section{3 熱処理による粒成長}

図6に $1800^{\circ} \mathrm{C}$ ，1時間で熱処理を施した焼結体の組 織を示す，微粉の場合 (a)は粒成長は起こっているも のの，組織は微細で均一である，サブミクロン粉焼 結体(b)では組織は粗大化しており, 長さ $5 \mu \mathrm{m}$ 以上に 針状に伸びた粒がみられ，不均一性は増大している。 見かけの平均円相当径は微粉焼結体では $0.39 \mu \mathrm{m}$, サ ブミクロン粉焼結体では1.02 $\mu$ m となった.

窒化けい素の粒成長の駆動力は主として粒径差と $\alpha$ から $\beta$ への相転移であるといわれている. 粒径差 による粒成長は，小さな粒子は大きな粒子と比較し て液相に対する溶解度が大きいため，小さな粒子が 液相に溶解し大きな粒子上に析出することにより粒 成長が起こる. 相転移に伴う粒成長は, 高温で不安 定相である原料中の $\alpha$ 粒子が液相に溶解し，それが 新たに液相から析出した $\beta$ 粒子あるいは原料粉中に わずかに含まれていた $\beta$ 粒子を核として析出するこ とにより起こる7". その際に核となる粒子が選択的

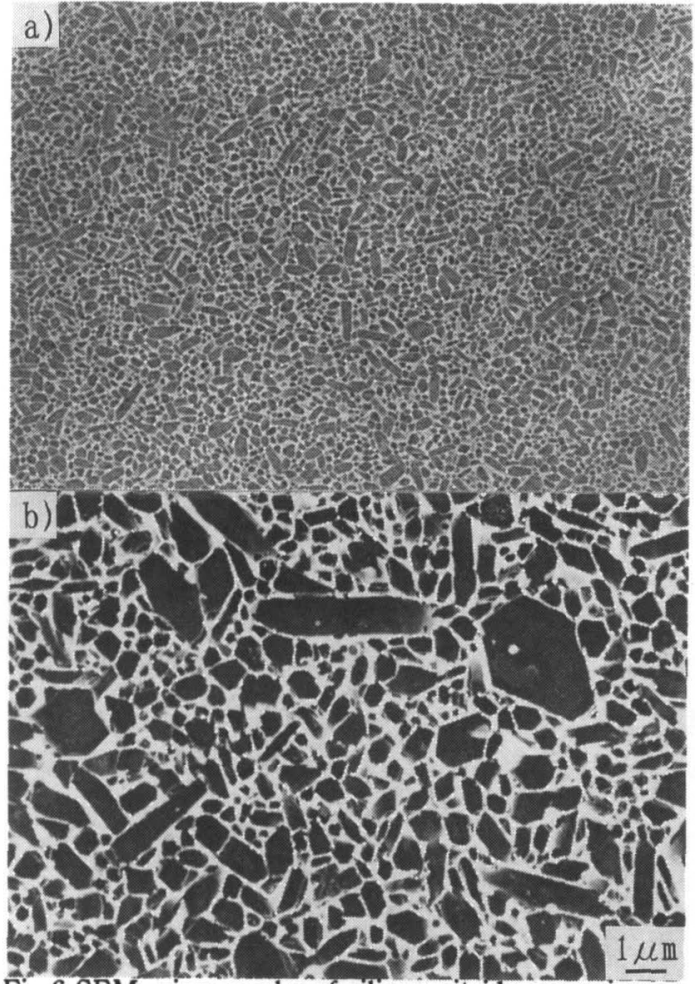

Fig.6 SEM micrographs of silicon nitride ceramics heat-treated at $1800{ }^{\circ} \mathrm{C}$ for $1 \mathrm{~h}$, (a) and (b) were prepared from fine and submicrometer powders, respectively.

に成長するが， $\alpha$ 粒子が残存している間は高い過飽 和度が維持されるので，異常粒成長を起こす。

今回の実験のように $\beta$ 型の窒化けい素を原料とし た場合には粒成長の駆動力は粒径差のみである，微 粉のホットプレス焼結体は均一な粒径のため, 粒成 長の駆動力が小さく，安定な微構造である．粒成長 速度は遅い，サブミクロン粉の場合は図4(b)からわ かるように，ホットプレス焼結体の粒径は微粉の場 合と比較して分布が広い。したがって粒成長の駆動 力が大きく, 微構造の安定性が低いため, 熱処理中 に顕著な粒成長が起こったものと考えられる． $\beta$ 型

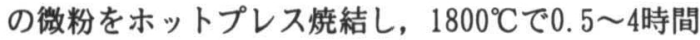
の熱処理により粒成長挙動を検討した結果では，熱 処理1時間までは粒成長するが，それ以上処理時間を 長くしても粒成長しない ${ }^{8)}$ ． $\beta$ 型のサブミクロン粉 の場合同樣に検討したところ, 熱処理時間が長くな るにしたがい, 粒成長し続ける ${ }^{9 !}$ 。この結果から， 微粉の場合は熱処理1時間では粒成長の駆動力がほと んどないため安定であるが, サブミクロン粉の場合 
は粒径差による駆動力が侤然として存在し，不安定 であると考えられる.

今回は高温安定な $\beta$ 型の粉体を用いたが， $\alpha$ 型の 場合には超塑性セラミックスの作製は難しいことが わかっている，微細で均一な $\alpha$ 型の原料粉を低温で 短時間にホットプレス焼結を行うと微細で均一な組 織の焼結体が得られるが，この焼結体を熱処理する と異常粒成長が起こってしまう4)， $\alpha$ 型を出発原料 としたガス压焼結の場合，焼結収縮のピークは温度 $1550 \sim 1800^{\circ} \mathrm{C}$ の間と $1800^{\circ} \mathrm{C}$ 以上の $2 つ の$ 温度域で現れ ることから, 窒化けい素の溶解一析出過程は2つの領 域に分けられる ${ }^{10)}$. 低温側の温度範囲では $а$ から への転移が起こり, 高密度化が進行するとともに粒 成長の核となる $\beta$ 粒子が生成する. 高温側の温度範 囲ではその $\beta$ 粒子が粒径差により選択的に成長し， ウイスカー強化複合材料のような複合組織が形成さ れる. 複合組儎の材料は異常粒成長により長く伸び た柱状粒子によるブリッジングや，き裂偏向等の機 構により勒性が高く，き裂進展抵抗も大きい" ${ }^{11}$ 。こ のような理由から従来高勒性の材料を作製するには $\alpha$ 型の原料が適しているとされてきた ${ }^{12)}$. 以上のよ うに相転移による粒成長では異常粒成長が起こるた め， $\alpha$ 型の場合には原料粉体の粒度を微細で均一に して均一組織の焼結体を作製しても，その焼結体の 微構造は相転移による粒成長の駆動力を保持してい るため不安定である.

\section{4 微構造の安定性}

窒化けい素/炭化けい素系の超塑性セラミックス の場合，焼結中の粒成長を抑え，動的な粒成長を抑 制するためにSi-C-N複合粉体を出発原料とし窒化け い素に第2相として炭化けい素を導入した. 引っ張り による塑性変形中に粒成長が観察され, 定ひずみ速 度の場合には負荷応力の增大を引き起こした．变形 前には約 $30 \%$ 存在していた $\alpha$ 窒化けい素は変形後には すべて $\beta$ 相に転移していた" . また $\alpha / \beta$ サイアロ ンの円板試料をドーム形に超塑性加工した例では加 工前に存在していた $\alpha$ サイアロンの一部あるいは全 ては加工後には $\beta$ サイアロンに転移していた．また 動的粒成長も観察されている ${ }^{13)}$ 。このように従来報 告されている超塑性窒化けい素材料では塑性加工中 の粒成長と加工硬化が報告されている.これは材料 中に高温では不安定な $\alpha$ 相を含んでいるためである. $\alpha$ から $\beta$ への転移という粒成長の駆動力を持ってい
るため微構造は不安定である.

しかし高温安定な $\beta$ 型単相の窒化けい素の場合に は，顕著な動的粒成長，加工硬化とも起こっていな い゙. これは安定な微構造であるからである。

超塑性変形中の粒成長は高温下での変形により誘 起された動的粒成長であり，単なる加熱による粒成 長（静的粒成長）とは異なる現象である.したがっ て今回の熱処理による実験では動的粒成長に対する 微構造の安定性を直接評価したことにはならない。 しかし，加工硬化は変形に要する時間が長い場合に 顕著であるという実験結果がいくつか報告されてい $ろ^{14,15)}$. Wangらは ${ }^{14)}$ 液相を含む微細な組織を持っ たセラミックスの超塑性の機構について 一メン（LiAlSi $2_{26}$ ）をモデル材に用い検討している. LiAlSi $20_{6}$ に過剩のSi $0_{2}$ を合んだ $\beta$ スポジューメンガ ラスを種々の条件で熱処理することにより結晶化さ せ, 粒径が0.9〜2.0 $\mu$ mのガラス相を含んだ多結晶体 を作製した.この材料を引っ張り応力下， $1150^{\circ} \mathrm{Cで}$ 変形させたところ，高いひずみ速度 $\left(6.7 \times 10^{-4} / \mathrm{s}\right)$ の場合，加工硬化はみられなかったが，低いひずみ 速度の場合 $\left(1.7 \times 10^{-4} / \mathrm{s}\right)$ には粒成長に伴う加工硬 化が起こった.この結果から塑性加工にともなうひ ずみよりも加工中に長時間高温状態にあることの方 が粒成長に及ほす影響が大きいことが示唆されてい る.また $\alpha / \beta$ サイアロンを圧縮応力下で超塑性変

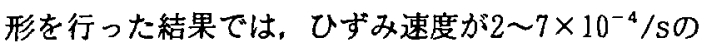
範囲では加工硬化がみられ， $1 \times 10^{-3} / \mathrm{s} の$ 場合には硬 化は起こっていない" ${ }^{15)}$ 。これらの結果から, 超塑性 変形中の硬化における長時間の加熱の影響はたいへ ん大きいことが示唆される.したがって熱処理だけ では超塑性変形時の安定性を直接評価したことには ならないが, 今回の結果から $\beta$ 型微粉をホットプレ スして作製したセラミックスの微構造が超塑性変形 中の動的粒成長に対して安定であることが推測でき る.

本研究の結果から微粉を原料とした焼結体の微構 造安定性は高く，サブミクロン粉の場合，安定性は 低かった。これは微粉の場合は粒径分布が狭い均一 な微構造のためである.この均一な微構造発現の理 由は微細で均一な原料粉体にある，超塑性空化けい 素を作製する際には単に平均的に微細な粒子を使用 するというだけでは不十分であり，均一な粒度をも つということが重要である，本実騟の結果と微細で 均一な粉末を出発原料とした場合でも $\alpha$ 型の粉末か 
らは安定な微棈造を持った空化けい素セラミックス は作製できないという著者らの結果" を考え合わせ ると， $\beta$ 型で微細かつ均一な粒度分布を持った粉体 がモノリシックな超塑性窒化けい素の作製には必要 であることがわかる.

\section{4 まとめ}

高温安定な $\beta$ 型で粒度が異なる2種類の窒化けい素 粉末の焼結举動と焼結体の微構造を比較・検討した. $0.5 \mu \mathrm{m}$ よりも大な粒子を含まない微細で均一な粒 度の粉末をホットプレス法を用いて焼結したところ， $1700^{\circ} \mathrm{C}$ で高密度化を達成し，焼結体組織は微細かつ 均一であった。このセラミックスは $1500^{\circ} \mathrm{C}$, 压縮応 カ下で超塑性を示した. ホットプレス焼結体を 1800 ${ }^{\circ} \mathrm{C} て ゙ 1$ 時間熱処理を行ったところ顕著な粒成長はみら れず，組織は微細で均一であったことから，この焼 結体は安定な微構造を持っていることがわかった。 一方 $0.5 \mu$ 凹りも大きな粒子を50\%含むサブミクロン

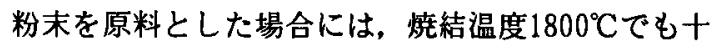
分な高密度化は達成できなかった，焼結体組織は均 一であったが粒成長が起こっていた，熱処理後の組 織は柱状に伸びた粒子がみられ不均一性が增大して いた．以上の結果から高温安定な $\beta$ 型で微細で均一 な原料粉体を用いることにより安定な微構造を持っ た超塑性窒化けい素を作製することができることが わかった.

\section{文献}

1) F. Maka i, Y. Kodama, S. Sakaguchi, N. Murayama, K. Izaki, K. Ni ihara: Nature, 344 (1990) 421.
2) I-T. Chen, L. A. Xue: J. Am. Ceram. Soc. 73 (1990) 2585.

3) M. Mi tomo, H. Hi rotsuru, H. Suematsu, T. Nishimura: J. Am. Ceram. Soc. 78 (1995) 211.

4）広津留秀樹, 三友護, 西村聡之：J.Ceram. Soc. Japan 投稿中

5) M. Mi tomo, N.Hirosaki, H. Hi rotsuru: MRS Bull., 20 (1995) 38.

6) M. Mi tomo, M. Tsutsumi, H. Tanaka, S. Uenosono, F. Sa i to: J. Am. Ceram. Soc. , 73 (1990) 2441.

7) D. -D. Lee, S. -J. Kang, G. Petzow, D. N. Yoon: J. Am. Ceram. Soc., 73 (1990) 767.

8) H. Hirotsuru, M. Mitomo, T. Nishimura: Proceeding of The second international conference on grain growth in polycrystalline materials, Kitakyusyu, May, 1995, in print.

9）広津留秀樹, 三友護, 西村聡之：J. Ceram. Soc. Japan, 103 (1995) 464.

10) M. Mitomo, N. Yang, Y. Kishi, Y. Bando: J. Mater. Sci., 23 (1988) 3413.

11) S. R. Choi, J.A. Salem: J. Am. Ceram. Soc. , 77 (1994) 1042.

12) F. F. Lange: J. Am. Ceram. Soc. , 62 (1979) 428.

13) S. -L. Hwang, I-W. Chen: J. Am. Ceram. Soc. , 77 (1994) 2575.

14) J-. G. Wang, R. Raj: J. Am. Ceram. Soc. , 67 (1984) 399.

15) I-W. Chen, S. -L. Hwang: J. Am. Ceram. Soc. 75 (1992) 1073. 